\title{
Preserved homograft function 32 years after surgery in a young patient
}

\author{
Ismail El-Hamamsy, MD, ${ }^{\mathrm{a}}$ James T. Willerson, MD, ${ }^{\mathrm{b}}$ and Magdi H. Yacoub, FRS, ${ }^{\mathrm{a}}$ London, \\ United Kingdom, and Houston, Tex
}

The quest for the ideal valve substitute, namely, a valve requiring no anticoagulation and free from early valve degeneration with a good hemodynamic profile, remains unsolved despite continued research over the past 50 years. The present report describes a well-functioning aortic root homograft 32 years after implantation. It illustrates the potential longevity of implanted tissue valves and highlights the need to better understand the cellular and molecular physiology of heart valves as well as the mechanisms responsible for structural valve degeneration.

From the Department of Cardiac Surgery, ${ }^{\mathrm{a}}$ Harefield Hospital, London, United Kingdom, and the Department of Cardiology, ${ }^{\mathrm{b}}$ Texas Heart Institute, Houston, Tex. Disclosures: None.

Received for publication Aug 12, 2009; accepted for publication Dec 9, 2009; available ahead of print March 25, 2010.

Address for reprints: Magdi H. Yacoub, FRS, Harefield Heart Science Center, Harefield Hospital, Hill End Rd, Harefield UB9 6JH, United Kingdom (E-mail: m.yacoub@imperial.ac.uk).

J Thorac Cardiovasc Surg 2010;139:e141-2

$0022-5223 / \$ 36.00$

Copyright (C) 2010 by The American Association for Thoracic Surgery

doi:10.1016/j.jtcvs.2009.12.025

\section{CLINICAL SUMMARY}

In 1977, a 36-year-old woman with a history of rheumatic fever complicated by rheumatic valve disease sought treatment. She reported having fatigue and exercise intolerance. Catheterization showed mixed aortic valve disease with a peak transvalvular gradient of $50 \mathrm{~mm} \mathrm{Hg}$ and moderate aortic regurgitation. There was concomitant moderate mitral valve stenosis. Left ventricular function and pulmonary artery pressures were within normal limits. Coronary angiography showed a $70 \%$ ostial stenosis in the right coronary artery. Total aortic root replacement using a "homovital" homograft with reimplantation of the coronary arteries was performed. Digital mitral valvotomy and a right coronary bypass using a saphenous vein graft were also performed. Postoperative recovery was uneventful.

The patient thereafter led a healthy and active life. She had no valve-related complications. She underwent mitral valve replacement with a mechanical prosthesis in 1996. At last follow-up, 32 years after the initial operation, she continues to be very active. Her latest echocardiogram in July 2009
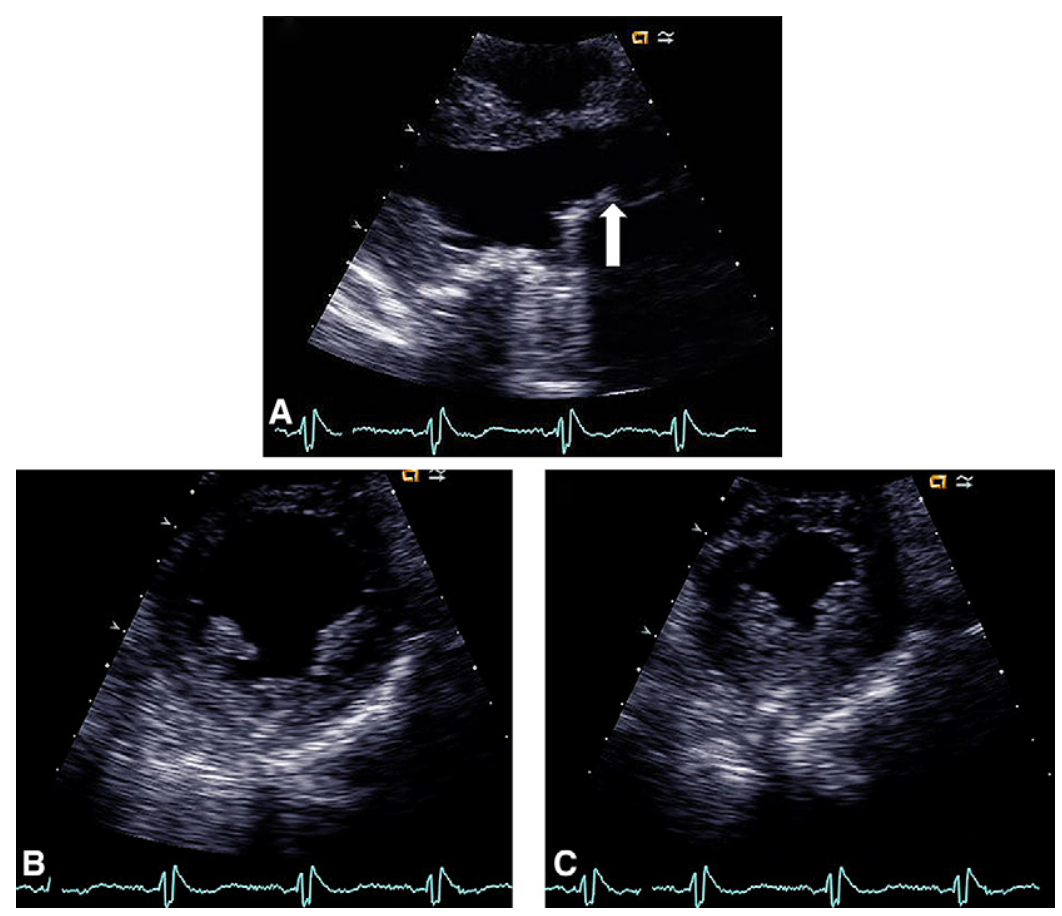

FIGURE 1. Echocardiographic evaluation 32 years after homograft total aortic root replacement showing (A) a long-axis view of the left ventricular outflow tract and aortic root with good opening of the valve (arrow) and sinus expansion, (B) short-axis end-diastolic view of the left ventricle, and (C) end-systolic view of the left ventricle showing good ventricular function. 
showed trace aortic regurgitation and a mean gradient of 8 $\mathrm{mm} \mathrm{Hg}$. Estimated aortic orifice area is $2.1 \mathrm{~cm}^{2}$ (indexed orifice area: $1.3 \mathrm{~cm}^{2} / \mathrm{m}^{2}$ ). Left ventricular end-diastolic and end-systolic diameters are 46 and $30 \mathrm{~mm}$, respectively (Figure 1). Left ventricular ejection fraction is preserved.

\section{DISCUSSION}

To our knowledge, this case represents the longest followup of a functional aortic homograft after implantation. Remarkably, the patient was in her mid-30s when she underwent surgery, putting her at high risk of early valve degeneration. Several points emerge from this case. Although we and others have sought to determine the precise mechanisms responsible for tissue valve deterioration, ${ }^{1,2}$ more work is required to translate this knowledge into improved patient outcomes. Homograft degeneration is partly due to direct and indirect immune reactions elicited by the persistence of living cells and protein remnants on the homograft cusps and wall. Interestingly, this case illustrates what we call the "homograft paradox," namely, that fresh homografts appear to be more durable and exhibit less degeneration despite a higher likelihood of eliciting an immune reaction. This might be due to their better ability to adapt to their new hemodynamic environment, therefore reducing stresses on the aortic cusps and wall. Similarly, use of a total root replacement technique (versus subcoronary implantation) is thought to favor the long-term durability of homografts, ${ }^{3}$ possibly due to better biomechanics of the homograft root, decreased mechanical stresses on the cusps, and more optimal ventricular workload and coronary blood flow. ${ }^{4}$

Bioprosthetic valve degeneration is characterized by lipid-rich inflammatory cell infiltration, ${ }^{2}$ a process similar to atherosclerosis, and is associated with smoking and concomitant coronary artery disease. ${ }^{5}$ In our patient, no recurrence of coronary artery disease was evidenced, mirroring the durability of the homograft. Her latest lipid profile is normal; she is normotensive, physically active, and eats a balanced diet. This underlines the potential impact of a healthy lifestyle and control of atherosclerotic risk factors in tissue valve recipients.

\section{CONCLUSION}

In conclusion, this case demonstrates the potential longterm functionality of an aortic homograft implanted as a total root in a young patient. With increased understanding of the mechanisms responsible for tissue valve degeneration, it is hoped that the durability of these valve substitutes can be greatly enhanced, including in the younger patient population.

\section{References}

1. Smith JD, Ogino H, Hunt D, Laylor RM, Rose ML, Yacoub MH. Humoral immune response to human aortic valve homografts. Ann Thorac Surg. 1995;60(2 Suppl): S127-30.

2. Shetty R, Pibarot P, Audet A, Janvier R, Dagenais F, Perron J, et al. Lipid-mediated inflammation and degeneration of bioprosthetic heart valves. Eur J Clin Invest. 2009;39:471-80.

3. Lund O, Chandrasekaran V, Grocott-Mason R, Elwidaa H, Mazhar R, Khaghani A, et al. Primary aortic valve replacement with allografts over twenty-five years: valve-related and procedure-related determinants of outcome. J Thorac Cardiovasc Surg. 1999; 117:77-90; discussion 91.

4. Davies JE, Parker KH, Francis DP, Hughes AD, Mayet J. What is the role of the aorta in directing coronary blood flow? Heart. 2008;94:1545-7.

5. El-Hamamsy I, Zaki M, Stevens LM, Clark L, Rubens M, Melina G, et al. Rate of progression and functional significance of aortic valve and root calcification following freestyle versus homograft aortic root replacement: results from a prospective randomized trial. Circulation. In press.

\section{Pericardial defects and traumatic tricuspid valve rupture: A serendipitous association?}

Giovanni Battista Luciani, MD, Fabio Patelli, MD, Giuseppe Faggian, MD, and Alessandro Mazzucco, MD, Verona, Italy

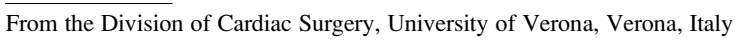
Disclosures: None.

Received for publication May 15, 2009; revisions received June 3, 2009; accepted for publication June 20, 2009; available ahead of print July 30, 2009.

Address for reprints: Giovanni Battista Luciani, MD, Division of Cardiac Surgery, University of Verona, OCM Piazzale Stefani 1, Verona, 37126, Italy (E-mail: giovanni.luciani@univr.it).

J Thorac Cardiovasc Surg 2010;139:e142-4

$0022-5223 / \$ 36.00$

Copyright (c) 2010 by The American Association for Thoracic Surgery doi:10.1016/j.jtcvs.2009.06.018
}

Traumatic tricuspid valve rupture (TTR) after blunt chest trauma is a fairly infrequent condition, although it is the most commonly reported traumatic valve injury. ${ }^{1}$ Rupture of the pericardium after chest trauma is relatively more frequent, but very few cases of TTR associated with pericardial rupture have been identified. ${ }^{2}$ Congenital pericardial defects are also rare with nearly 200 cases reported to date. ${ }^{3}$ Here reported is the case of successful repair of TTR associated with a pericardial defect. The issue whether the pericardial defect is a consequence of trauma or 